\title{
Anti-Insulin Receptor Antibodies Mimic the Effects of Insulin on the Activities of Pyruvate Dehydrogenase and AcetylCoA Carboxylase and on Specific Protein Phosphorylation in Rat Epididymal Fat Cells
}

\author{
G. J. Belsham, R. W. Brownsey, W. A. Hughes, and R. M. Denton \\ Department of Biochemistry, University of Bristol Medical School, Bristol, England
}

\begin{abstract}
Summary. Previous studies have shown that autoantibodies against insulin receptors found in certain patients with severe insulin resistance stimulate glucose transport and metabolism in fat cell and muscle preparations. The present studies show that preincubation of rat epididymal adipose tissue with $1: 1000$ dilution of one such serum results in a two fold increase in the initial activities of pyruvate dehydrogenase and acetylCoA carboxylase. These increases are similar to the maximum effects of insulin. Incubation of isolated fat cells with the serum at the same concentration also resulted in the increased phosphorylation of three intracellular proteins with subunit molecular weights of $130,000,35,000$ and 22,000 to the same extent as observed with insulin. These findings lend further support to the view that the short term effects of insulin do not involve the entry of the insulin molecule (or part thereof) into cells of target tissues.
\end{abstract}

Key words: Anti-insulin receptor antibodies, insulin effects, pyruvate dehydrogenase, acetylCoA carboxylase, specific protein phosphorylation, protein inhibitor $\left(\mathrm{I}_{1}\right)$ of the general phosphoprotein phosphatase.

Many important questions about the mechanism whereby insulin, after first binding to specific receptors on the outside of cells, causes changes in the activities of a range of key enzymes within cells remain unanswered [1]. One such question is whether the action of insulin requires that the insulin molecule (or part thereof) enters the cells of the target tissue [2-4].

Recent studies of Kahn and his colleagues have identified a group of patients characterized by severe insulin resistance and acanthosis nigricans who appear to have high concentrations of circulating antibodies to the insulin receptor present in the plasma membranes of muscle, adipose tissue and liver cells [5-8]. These antibodies have been found to stimulate glucose transport and metabolism in fat and muscle preparations to a similar extent to insulin [6, 8]. It seems reasonable to assume that if these immunoglobulins bring about changes in the activities of intracellular enzymes similar to those observed with insulin then it is unlikely that insulin's effects on those enzymes involves internalization of the whole or part of the insulin molecule [4]. Indeed, very recent studies by Lawrence and others have shown that the antibodies do bring about changes in the activities of glycogen synthase and phosphorylase in fat cells very similar to those observed with insulin [4]. However, in apparent contrast, the antibodies from the same patient did not appear to stimulate glycogen synthesis in the mouse soleus preparation to the same extent as insulin [8].

In the present study, we have explored the effects of the same serum on other intracellular processes in rat epididymal adipose tissue and fat cells which are affected by insulin. These include the activities of both pyruvate dehydrogenase and acetylCoA carboxylase, which are increased by about 2 fold within a few minutes of exposure of the tissue to insulin [9-12] and the phosphorylation of specific proteins within fat cells. This can be studied by incubating the cells with ${ }^{32} \mathbf{P}_{\mathrm{i}}$ followed by extraction and the separation of the labelled phosphoproteins by SDS-polyacrylamide gel electrophoresis [13-15]. With this technique we have been able to demonstrate directly that the activation of pyruvate dehydrogenase in the presence of insulin is due to dephosphorylation of the enzyme $[12,15]$.

Phosphorylation of acetylCoA carboxylase in fat cells has also been demonstrated $[16,17]$ but the role 


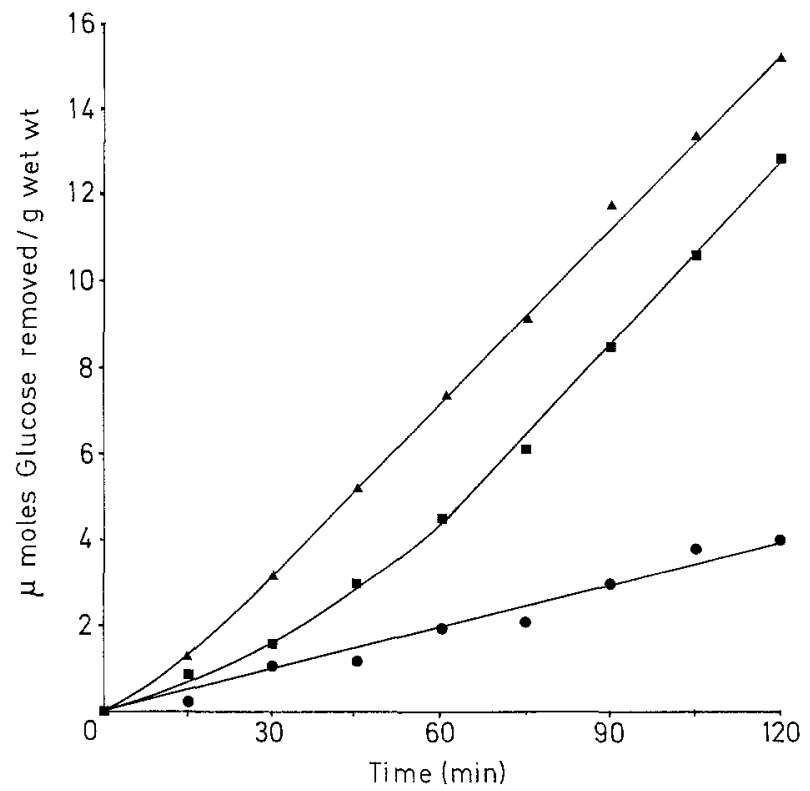

Fig. 1. Time courses of glucose uptake by adipose tissue pieces incubated in Krebs Henseleit bicarbonate medium containing glucose $(5 \mathrm{mmol} / \mathrm{l})$ and the following additions: none; $\boldsymbol{\Delta}$ insulin $(0.5 \mu \mathrm{g} / \mathrm{ml}) ; \quad$ anti-insulin receptor serum B-2 $(1 \mu \mathrm{l} / \mathrm{ml})$. The pieces were preincubated for $30 \mathrm{~min}$ in medium without additions before the start of the incubation period

of changes in phosphorylation in the effects of insulin on the activity of this enzyme has yet to be established [16]. Insulin is also known to cause a marked increase in the phosphorylation of two intracellular proteins of subunit molecular weights of 130,000 [13-16] and 35,000 [12, 15]. During the present studies, the increased phosphorylation of the third protein (subunit molecular weight of 22,000) in fat cells with insulin was recognised.

\section{Materials and Methods}

\section{Animals}

Epididymal fat pads were obtained from male albino Wistar rats $(180-200 \mathrm{~g})$ with free access to water and stock laboratory diet (modified 41B; Oxoid Ltd., London, S.E. 1, U. K.).

\section{Serum Containing Anti-Insulin Receptor Antibodies}

This was the kind gift of Dr. C. R. Kahn (Diabetes Branch, National Institute of Arthritis, Metabolism and Digestive Diseases, National Institutes of Health, Bethesda, Maryland 20014). It had previously been designated serum B-2 [5] and was the same as that used in a number of previous studies with fat cell preparations $[4,6,7]$.

\section{Insulin}

Stock solutions were prepared by dissolving $0.5 \mathrm{mg} / \mathrm{ml}$ bovine insulin (Sigma London Chemical Co. Ltd., Poole, Dorest, U. K.) in $3 \mathrm{mM}$ hydrochloric acid and stored at $-20^{\circ} \mathrm{C}$ until use.

\section{Measurement of Glucose Uptake and Enzyme Activities in Epididymal Fat Pad Pieces}

The pads were cut into small pieces of about $50 \mathrm{mg}$ and incubated at $37^{\circ} \mathrm{C}$ in groups of 6 to 8 in $3.5 \mathrm{ml}$ of Krebs-Henseleit bicarbonate buffered medium ( $\mathrm{pH} 7.4$ with $1.25 \mathrm{mmol} / 1 \mathrm{CaCl}_{2}$ ) containing glucose $(5 \mathrm{mmol} / \mathrm{l})$ and appropriate additions of insulin or serum B-2 as indicated and gassed with $\mathrm{O}_{2}: \mathrm{CO}_{2}(95: 5)$.

At the end of the incubation period, samples of medium were treated with perchloric acid $(0.1 \mathrm{mmol} / \mathrm{l})$ and assayed for glucose [20]. The pieces of adipose tissue were rapidly frozen with liquid nitrogen immediately on completion of the incubation.

The frozen pieces were then extracted and the initial and total activities of acetylCoA carboxylase (EC 6.4.1.2.) and pyruvate dehydrogenase assayed as described previously [21, 22]. Total activities of the enzymes were taken as the activities in extracts following treatment with citrate or pyruvate dehydrogenase phosphate phosphatase respectively. Enzyme activites have been expressed as munits where one munit is the amount catalysing the conversion of $1 \mathrm{nmol}$ of subststrate in $1 \mathrm{~min}$ at $30^{\circ} \mathrm{C}$.

\section{Determination of Phosphorylation of Proteins in Isolated Fat Cells}

The techniques followed those described previously [15-17]. In brief, isolated fat cells were prepared by collagenase digestion and then pre-incubated with ${ }^{32} \mathrm{P}_{\mathrm{i}}(0.2 \mathrm{mmol} / 1$ and about $1000 \mathrm{dpm} /$ pmol) for $1 \mathrm{~h}$ followed by incubation for a further $15 \mathrm{~min}$ in the presence of appropriate additions of insulin or serum. The cells were broken by vortexing in cold medium (sucrose $(0.25 \mathrm{~mol} / 1)$ containing Tris $(10 \mathrm{mmol} / \mathrm{l})$ ethylene glycol-bis-(amino-ethylether)-tetra-acetate (EGTA) $(2 \mathrm{mmol} / \mathrm{l})$ and reduced glutathione $(7.5 \mathrm{mmol} / \mathrm{l}), \mathrm{pH} 7.4)$. Following the removal of fat by brief centrifugation $(1000 \mathrm{~g} / \mathrm{min})$, extracted proteins were immediately precipitated with trichloracetic acid $(10 \% \mathrm{w} / \mathrm{v})$. These proteins were redissolved in gel buffer which contained sodium dodecylsulphate (SDS) $(40 \mathrm{mg} / \mathrm{ml})$, sucrose $(200 \mathrm{mg} / \mathrm{ml})$, Tris $(62.5 \mathrm{mmol} / \mathrm{l})$, bromophenol blue $(0.2 \mathrm{mg} / \mathrm{ml})$ and 2-mercaptoethanol $(100 \mathrm{mmol} / \mathrm{l}), \mathrm{pH} 6.8$ and heated at $100^{\circ} \mathrm{C}$ for $5 \mathrm{~min}$. Separation of the proteins was carried out using SDS-polyacrylamide gel electrophoresis in $1 \mathrm{~cm}$ tracks on $10 \%(\mathrm{w} / \mathrm{v})$ or $12 \%(\mathrm{w} / \mathrm{v})$ polyacrylamide slab gels $(14 \mathrm{~cm} \times 14 \mathrm{~cm})$ using solutions as described by Laemmli [23]. After electrophoresis the proteins were fixed and then stained with Coomassie Blue and the gels laid on cellophane and dried on boards under vacuum. The dried gels were exposed to Kodak Kodirex KT X-ray film and the autoradiographs scanned at $625 \mathrm{~nm}$ in a Gilford recording spectrophotometer.

\section{Results}

Effects of Anti-Insulin Receptor Serum B-2 on Glucose Uptake by Pieces of Rat Epididymal Adipose Tissue and Isolated Fat Cells

Figure 1 illustrates the effects of insulin and the serum B-2 on the time course of glucose uptake by rat epididymal adipose tissue pieces. The uptake of 
Table 1. Effect of insulin and anti-insulin receptor serum B-2 on the uptake of glycose and the initial activities of pyruvate dehydrogenase and acetylCoA carboxylase in rat epididymal adipose tissue pieces

\begin{tabular}{|c|c|c|c|c|c|c|c|}
\hline \multirow[b]{3}{*}{ Additions to medium } & \multirow[b]{3}{*}{$\begin{array}{l}\text { Glucose uptake } \\
(\mu \mathrm{mol} / \mathrm{h} / \mathrm{g} \text { wet } \mathrm{wt})\end{array}$} & \multicolumn{6}{|c|}{ Enzyme activities (as munit/g wet wt) } \\
\hline & & \multicolumn{3}{|c|}{ Pyruvate dehydrogenase } & \multicolumn{3}{|c|}{ AcetylCoA carboxylase } \\
\hline & & Initial (I) & Total $(\mathrm{T})$ & $100 \mathrm{I} / \mathrm{T}$ & Initial (I) & Total $(\mathrm{T})$ & $100 \mathrm{I} / \mathrm{T}$ \\
\hline None (control) & $2.24 \pm 0.15(8)$ & $61.3 \pm 6.5$ & $158 \pm 25$ & $41 \pm 3.5(7)$ & $21 \pm 2.4$ & $123 \pm 16$ & $18 \pm 1.2(8)$ \\
\hline Insulin $(0.5 \mu \mathrm{g} / \mathrm{ml})$ & $8.55 \pm 1.24(4)^{b}$ & $118 \pm 16^{\mathrm{b}}$ & $177 \pm 32$ & $69 \pm 9.3(4)^{b}$ & $43 \pm 7.5^{b}$ & $137 \pm 7.4$ & $31 \pm 4.1(4)^{\mathrm{a}}$ \\
\hline $\begin{array}{l}\text { Anti-insulin receptor } \\
\text { serum B-2 }(1 \mu \mathrm{l} / \mathrm{ml})\end{array}$ & $6.34 \pm 1.13(4)^{\mathrm{b}}$ & $121 \pm 16^{\mathrm{b}}$ & $150 \pm 8$ & $80 \pm 6.1(4)^{b}$ & $40 \pm 3.9^{\mathrm{b}}$ & $115 \pm 21$ & $37 \pm 3.7(4)^{b}$ \\
\hline
\end{tabular}

Adipose tissue pieces were preincubated for $30 \mathrm{~min}$ in medium containing glucose $(5 \mathrm{mmol} / \mathrm{l})$ and other additions as indicated and then transferred to fresh medium of the same composition and incubated for a further $60 \mathrm{~min}$. Glucose uptake, pyruvate dehydrogenase and acetylCoA carboxylase activities were determined as described in Methods. All results are shown as mean \pm SEM for the number of separate observations given in parenthesis

a $\mathrm{P}<0.05$; $\mathrm{b} \mathrm{P}<0.01$ versus control value

glucose was increased fourfold by a saturating concentration of insulin $(0.5 \mu \mathrm{g} / \mathrm{ml})$ within $15 \mathrm{~min}$. The addition of serum B-2 $(1 \mu \mathrm{l} / \mathrm{ml})$ leads to a similar maximum stimulation in glucose uptake but this was only achieved after about $1 \mathrm{~h}$ of exposure to the serum.

Table 1 shows the effects of the same concentrations of insulin and serum B-2 measured over a $60 \mathrm{~min}$ period following a $30 \mathrm{~min}$ preincubation period also in the presence of either insulin or serum B-2. Again a fourfold increase in glucose uptake was observed in the presence of insulin. The increase in the presence of the serum B-2 was about three fold, consistent with the time course shown in Figure 1.

\section{Effects of Anti-Insulin Receptor Serum B-2 on the Initial Activities of Pyruvate Dehydrogenase and AcetylCoA Carboxylase}

The exposure to insulin resulted in significant increases in the initial activity of both pyruvate dehydrogenase and acetylCoA carboxylase measured in tissue extracts prepared at the end of the incubation period (Table 1). Initial activities were also increased in tissue pieces incubated with serum B-2 $(1 \mu \mathrm{l} / \mathrm{ml})$ by at least the same extent as that observed with insulin (Table 1). The actual percentage increases in initial activities of pyruvate dehydrogenase and acetylCoA carboxylase (based on paired control values) with insulin were $92 \pm 30(4)$ and $78 \pm$ 23 (4) respectively whereas those in the presence of serum B-2 $(1 \mu \mathrm{l} / \mathrm{ml})$ were $111 \pm 31(3)$ and $117 \pm 33$ (4) respectively. A second similar series of experiments were conducted using $0.5 \mu \mathrm{l} / \mathrm{ml}$ of the serum. The percentage increases in initial activities of pyruvate dehydrogenase and acetylCoA carboxylase with insulin $(0.5 \mu \mathrm{g} / \mathrm{ml})$ were $87 \pm 19(8)$ and $125 \pm 51$ (7) respectively whereas those in the presence of serum B-2 $(0.5 \mu \mathrm{l} / \mathrm{ml})$ were $53 \pm 10(7)$ and $79 \pm 19$ (7). Results are given as mean \pm SEM for the number of paired observations given in parenthesis.

No significant changes in the total activities of either enzyme were observed with insulin or serum B-2 (Table 1).

\section{Effects of Anti-Insulin Receptor Serum B-2 on the Phosphorylation of Proteins in Isolated Fat Cells}

Figures $2 \mathrm{a}$ and 3 (trace a) show the densitometric scans of autoradiographs of $\left[{ }^{32} \mathrm{P}\right]$ labelled phosphoproteins from fat cells incubated under standard conditions in the presence of ${ }^{32} \mathrm{P}_{i}$ for $75 \mathrm{~min}$. The phosphoproteins were separated by SDS-polyacrylamide gel electrophoresis. The numbers of the bands given in the figures correspond to those given in previous studies using phosphate gels with $7.5 \%$ polyacrylamide and the period of incubation was sufficient to achieve their maximum steady-state labelling [15, 16]. In the present studies, the labelled phosphoprotein band originally designated band 1 (which is largely acetylCoA carboxylase) was not well separated from the interface between the spacer $4 \%$ gel and the separating 10 or $12 \%$ gel. On the other hand, these systems revealed additional bands representing phosphoprotein with subunit molecular weights of about 22,000 and 18,000 which were not separated from the solvent front in our earlier studies. These we have designated band 9 and band 10 . In particular the $12 \%$ gel clearly resolved band 7 and band 9 and enabled the changes in these bands to be seen more clearly (Figs. 2 and 3). 


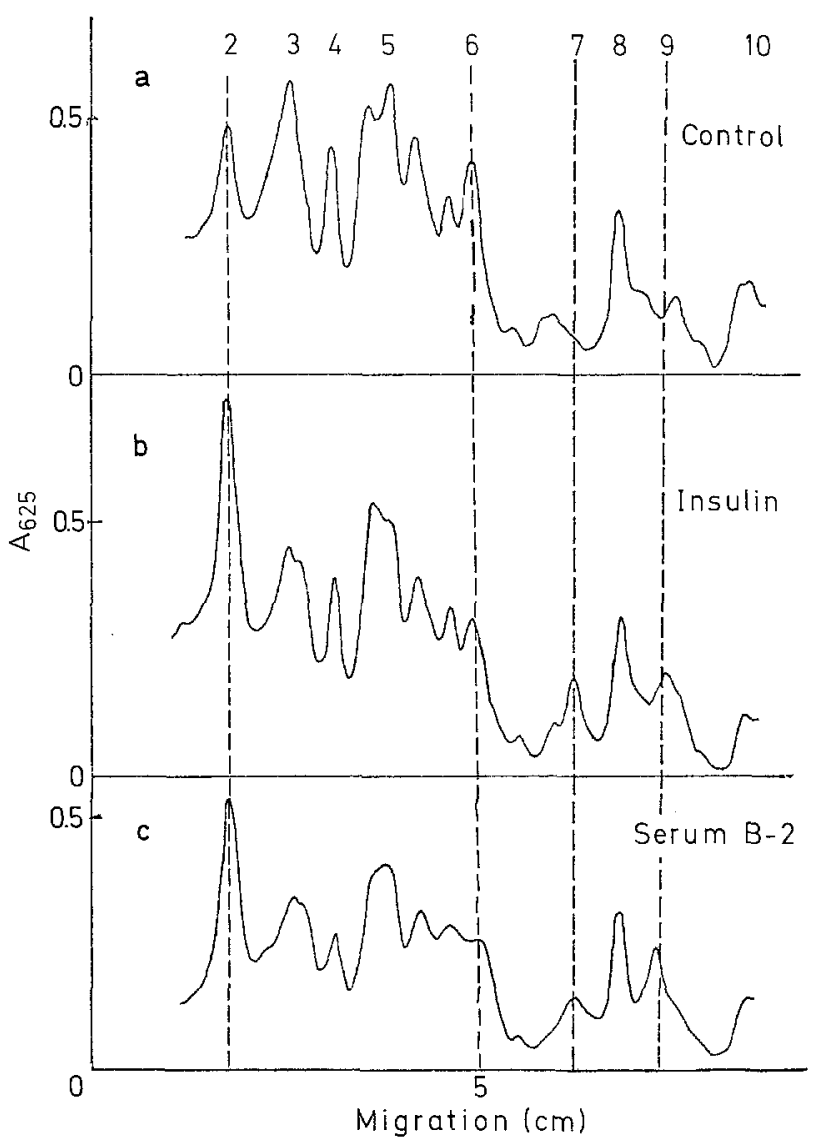

Fig. 2. Densitometric traces of autoradiographs of $\left[{ }^{32} \mathrm{P}\right]$ labelled phosphoproteins from fat cells separated by SDS-polyacryamide $(10 \% \mathrm{w} / \mathrm{v})$ slab-gel electrophoresis. Fat cells were incubated for $1 \mathrm{~h}$ in medium containing $\left[{ }^{32} \mathrm{P}\right]$ phosphate, albumin $(10 \mathrm{mg} / \mathrm{ml})$ and glucose $(1 \mathrm{mM})$ and then for a further $15 \mathrm{~min}$ in the same medium with the following additions: (a) none; (b) insulin $(0.5 \mu \mathrm{g}$ / $\mathrm{ml})$; (c) anti-insulin receptor serum B-2 $(1 \mu \mathrm{l} / \mathrm{ml})$. The dye front (bromophenol blue) was allowed to migrate $10 \mathrm{~cm}$. Results are typical of experiments carried out on three different preparations of cells. Also indicated are the protein band numbers used in the text

It can be seen from Figures $2 b$ and 3 (trace $b$ ) that when insulin was added to the incubation medium for the last $15 \mathrm{~min}$ the extent of phosphorylation of bands 2 and 7 was greatly increased. These bands have subunit molecular weights of approximately 130,000 and 35,000 respectively. It is also evident that the phosphorylation of a further smaller protein was increased. This is the band designated 9 and has a subunit molecular weight of about 22,000 . On the other hand, exposure to insulin also resulted in a small descrease in the phosphorylation of band 6 (which contains the phosphorylated $\alpha$-subunit of pyruvate dehydrogenase $[12,15]$.

Figures $2 \mathrm{c}$ and 3 (trace $\mathrm{c}$ ) show the scans of the labelled phosphoprotein in cells exposed to $1 \mu \mathrm{l} / \mathrm{ml}$

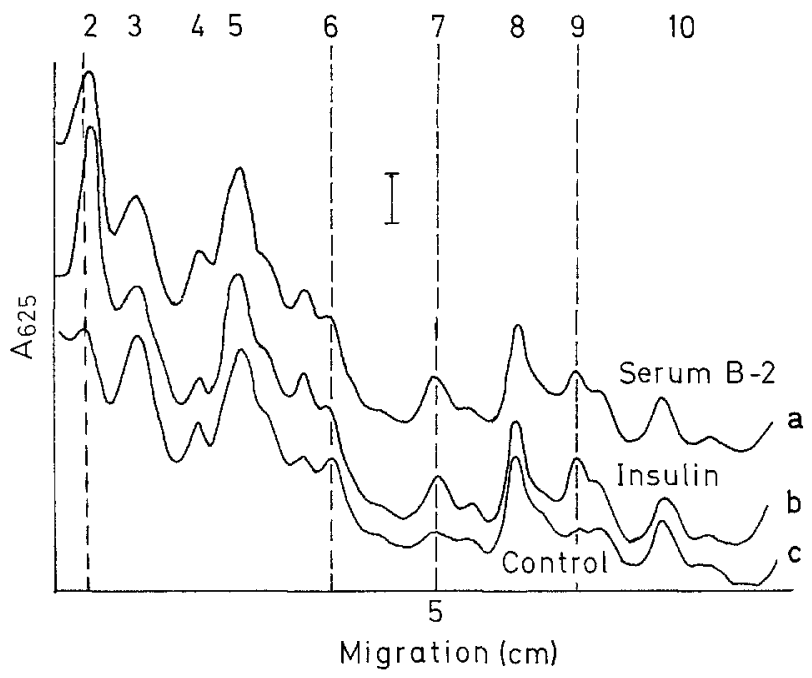

Fig. 3. Experimental details are the same as for Figure 1. Except that a $12 \%(\mathrm{w} / \mathrm{v})$ polyacrylamide gel was used. This separation was carried out on samples from the same experiment as shown in Figure 1. The baselines of the different traces have been separated for the sake of clarity. The bar represents ${ }^{A} 625 \mathrm{~nm}=0.2$. Additions to the cells were: (a) none (b) insulin $(0.5 \mu \mathrm{g} / \mathrm{ml})$ (c) antiinsulin receptor serum $\mathrm{B}-2(1 \mu \mathrm{l} / \mathrm{ml})$

serum B-2 for $15 \mathrm{~min}$. As with insulin, the phosphorylation of bands 2,7 and 9 were all clearly increased whereas that of band 6 was decreased. The traces shown in Figures 2 and 3 are taken from one of three similar experiments with different batches of cells. In all cases the serum $(1 \mu \mathrm{l} / \mathrm{ml})$ resulted in changes in bands $2,6,7$ and 9 which were similar to those observed with insulin.

\section{Discussion}

Previous studies on the effects of the serum B-2 on glucose uptake, glucose metabolism, glycogen synthase activity and phosphorylase activity in fat cells showed that maximum effects were observed at about $1 \mu \mathrm{l} / \mathrm{ml}[4,6]$. At this concentration the changes observed with the serum B-2 were as large as those observed with saturating concentrations of insulin, were not effected by the presence of antiinsulin serum but were largely lost on the addition of anti-IgG serum $[4,6]$. No additional effects of insulin were observed in the presence of $1 \mu \mathrm{l} / \mathrm{ml}$ of the serum B-2 [6].

The present studies demonstrate that the serum B-2 at the concentration of $1 \mu \mathrm{l} / \mathrm{ml}$ also causes increases in the initial activities of pyruvate dehydrogenase (a mitochondrial enzyme) and acetylCoA carboxylase (a cytoplasmic enzyme) in adipose tissue pieces (Table 1). These increases were at least as 
large as those observed with saturating concentrations of insulin. There was a considerable lag period before the maximum effect of serum B-2 was observed on glucose uptake by adipose tissue pieces. We presume this lag reflects the slow penetration by the antibodies into the tissue pieces compared to insulin. No such lag period appeared to exist in the effects of the serum B-2 on isolated fat cells. Changes in the phosphorylation of proteins similar to those observed with insulin in isolated fat cells were evident after $15 \mathrm{~min}$. These changes included a decrease in the phosphorylation of band 6 (which contains the $\alpha$-subunit of pyruvate dehydrogenase) and increases in the phosphorylation of bands 2,7 and 9. The effect of insulin on the phosphorylation of band 6 was smaller than that found previously $[12,15]$. With the batches of collagenase available to us at the time of these studies, pyruvate dehydrogenase in the fat cells appeared to be largely dephosphorylated and thus the initial activity was close to the total activity even in the absence of insulin. We have encountered this problem before [24].

Taken together with the studies of Lawrence et al. [4], our results suggest that the serum B-2 may be capable of initiating all the short term intracellular effects of insulin in adipose tissue. All the effects studied appear to be largely independent of the stimulation of glucose transport $[4,11$, unpublished observations by R. W. B. and W. A. H.]. The findings lend further support to the view that the short-term intracellular effects of insulin are bought about by mechanisms which do involve transfer of the insulin molecule, or part thereof, into cells. It would appear that the interaction of insulin or anti-insulin receptor antibodies with the insulin receptors in the cell membrane bring about changes, perhaps including aggregation [25], in the insulin receptor which initiate the generation of an unknown signal (or signals) within the cells which in turn leads to the observed intracellular events.

Evidence for the internalization of ${ }^{125} \mathrm{I}$-insulin into liver cells has been recently reported but since much of the labelled insulin was found associated with the lysosomes this may be a degradative pathway [26]. Insulin binding has been observed with preparations of nuclei and other intracellular organelles from rat liver [2]. However, serum B-2 does not inhibit the binding of insulin to the nuclei and thus it would seem unlikely that the antibodies could elicit any biological activity at these sites [2].

The present studies also serve to underline that the effects of insulin on cells probably involve increases in phosphorylation of certain proteins as well as the dephosphorylation of others, such as pyruvate dehydrogenase and glycogen synthase. The physiological importance of the phosphorylation of the three proteins showing increased phosphorylation after $15 \mathrm{~min}$ exposure of fat cells to insulin (or the serum B-2) has not been fully characterized. The protein of subunit molecular weight 130,000 may be ATP-citrate lyase $[27,28]$ and that of 35,000 may be a ribosomal protein $[11,29]$. The smallest of the three phospho-proteins (band 9; subunit molecular weight 22,000), which was first recognised during the course of these studies, may be the inhibitor protein, known as $I_{1}$ of the general phosphoprotein phosphatase $[18,19]$. This protein becomes a potent inhibitor of the phosphatase when phosphorylated on a specific threonine residue by cyclic AMP dependent protein kinase [18, 19, 29]. Evidence that band 9 may represent the phosphorylation of this protein may be summarised as follows: (i), the apparent subunit molecular weight on SDS-polyacrylamide gel electrophoresis; (ii), the phosphorylation of the protein in fat cells is also brought about by adrenaline (iii), the protein is the only labelled phosphoprotein which is not precipitated with $2 \%$ trichloroacetic acid or by heating at $100{ }^{\circ} \mathrm{C}$ for $10 \mathrm{~min}$, but is precipitated by $10-15 \%$ trichloroacetic acid [unpublished observations of G. J. B.].

Acknowledgements. We are indebted to Dr. C. R. Kahn for the gift of the antiserum and for arranging its transfer to England. These studies were supported by grants from the Medical Research Council and the British Diabetic Association. G. J. B. holds a postgraduate scholarship awarded by the University of Bristol.

\section{References}

1. Czech MP (1977) Molecular basis of insulin action. Annu Rev Biochem 46:359

2. Goldfine ID (1978) Insulin receptors and the site of insulin action. Life Sci 23:2639

3. Kahn CR, Baird KL (1978) The fate of insulin bound to adipocytes. J Biol Chem 253:4900

4. Lawrence JC, Larner J, Kahn CR, Roth J (1978) Auto-antibodies to the insulin receptor activate glycogen synthase in rat adipocytes. Mol Cell Biochem 22:153

5. Kahn CR, Flier JS, Bar RS, Archer JA, Gorden P, Martin MM, Roth J (1976) The syndromes of insulin resistance and acanthosis nigricans. Insulin-receptor disorders in man. $\mathrm{N}$ Engl J Med 294:739-745

6. Kahn CR, Baird K, Flier JS, Jarrett DB (1977) Effects of autoantibodies to the insulin receptor on isolated adipocytes. Studies of insulin binding and insulin action. J Clin Invest 60:1094-1106

7. Jarrett DB, Roth J, Kahn CR, Flier JS (1976) Direct method for the detection and characterization of cell surface receptors for insulin by means of ${ }^{125}$-labelled auto-antibodies against the insulin receptor. Proc Natl Acad Sci USA 73:4115

8. LeMarchand-Brustel Y, Gorden P, Flier IS, Kahn CR, Freychet P (1978) Anti-insulin receptor antibodies inhibit insulin binding and stimulate glucose metabolism in skeletal muscle. Diabetologia 14:311 
9. Denton RM, Randle PJ, Bridges BJ, Cooper RH, Kerbey AL, Pask HT, Severson DL, Stansbie D, Whitehouse S (1975) Regulation of mammalian pyruvate dehydrogenase. Mol Cell Biochem 9:27

10. Halestrap AP, Denton RM (1974) Hormonal regulation of adipose tissue acetylCoA carboxylase by changes in the polymeric state of the enzyme. Biochem J 142:365

11. Denton RM, Bridges BJ, Brownsey RW, Evans GL, Hughes WA, McCormack J (1978) Acute hormonal regulation of fatty acid synthesis in mammalian tissue. In: Dils $\mathbf{R}$, Knudsen $\mathbf{J}$ (eds) Regulation of fatty acid \& glycerolipid metabolism. Pergamon Press, Oxford, p 21

12. Denton RM, Hughes WA (1978) Minireview, pyruvate dehydrogenase and the hormonal regulation of fat synthesis in mammalian tissues. Int $\mathbf{J}$ Biochem 9:545

13. Benjamin WB, Singer I (1975) Action of insulin, epinephrine and dibutyryl cyclic adenosine 5 -monophosphate on fat cell protein phosphorylation. Cyclic adenosine $5^{\prime}$-monophosphate dependent and independent mechanisms. Biochemistry $14: 3301$

14. Avruch J, Leone GR, Martin DB (1976) Identification and subcellular distribution of adipocyte peptides and phosphopeptides. J Biol Chem 251:1505

15. Hughes WA, Brownsey RW, Denton RM (1977) The effect of insulin on the phosphorylation of pyruvate dehydrogenase and other proteins in adipose tissue. In: Pinna LA (ed) Phosphorylated proteins and related enzymes. Information Retrieval, London, $\mathrm{p} 17$

16. Brownsey RW, Hughes WA, Denton RM, Mayer RJ (1977) Demonstration of the phosphorylation of acetylCoA carboxylase within rat epididymal fat cells. Biochem J 168:441

17. Brownsey RW, Hughes WA, Denton RM (1979) Adrenaline and the regulation of acetyl-coenzyme $A$ carboxylase in rat epididymal adipose tissue. Biochem J 184:23

18. Huang FL, Glinsmann WH (1976) Separation and characterization of two phosphorylase phosphatase inhibitors from rabbit skeletal muscle. Eur J Biochem 70:419

19. Foulkes JG, Cohen $P$ (1979) In vivo phosphorylation of inhibitor $\mathrm{I}$ from rabbit skeletal muscle in response to adrenaline. Eur J Biochem 97:251

20. Slein MW (1975) D-Glucose determination with hexokinase and glucose-6-phosphate dehydrogenase. In: Bergmeyer HU (ed) Methods of enzymatic analysis. Academic Press, London New York, p 117

21. Stansbie D, Brownsey RW, Crettaz M, Denton RM (1976) Acute effects in vivo of anti-insulin serum on rates of fatty acid synthesis and activities of acetylCoA carboxylase and pyruvate dehydrogenase in liver and epididymal adipose tissue of fed rats. Biochem J 160:413

22. McCormack JG, Denton RM (1977) Evidence that fatty acid synthesis in the interscapular brown adipose tissue of cold adapted rats is increased in vivo by insulin by mechanisms involving paralled activation of pyruvate dehydrogenase and acetylCoA carboxylase. Biochem J 166:637

23. Laemmli UK (1970) Cleavage of structural proteins during the assembly of the head of bacteriophage T4. Nature 227:680

24. Severson DL, Denton RM, Bridges BJ, Pask HT, Randle PJ (1976) Exchangeable and total calcium pools in mitochondria of rat epididymal fat cells. Biochem J 154:209

25. Kahn CR, Baird KL, Jarrett DB, Flier JS (1978) Direct demonstration that receptor crosslinking or aggregation is important in insulin action. Proc Natl Acad Sci USA 75:4209

26. Carpentier $J$, Gorden $P$, Barazzone $P$, Freychet $P$, Le Cam A, Orci L (1979) Intracellular localization of ${ }^{125}$ I-labelled insulin in hepatocytes from intact rat liver. Proc Natl Acad Sci USA $76: 2803-2807$

27. Linn TC, Srere PA (1979) Identification of ATP citrate lyase as a phosphoprotein. J Biol Chem 254:1691-1698

28. Alexander MC, Kowaloff EM, Witters LA, Dennihy DT, Avruch J (1979) Purification of. hepatic 123,000 dalton hormone stimulated ${ }^{32}$ P-peptide and its identification as ATP citrate lyase. J Biol Chem 245: 8052-8056

29. Smith CJ, Wejksnora PJ, Warner JR, Rubin CS, Rosen OM (1979) Insulin-stimulated protein phosphorylation in 3T3-L1 preadipocytes. Proc Natl Acad Sci USA 76:2725-2729

30. Cohen P, Rylatt DB, Nimmo GA (1977) The hormonal control of glycogen metabolism; the amino acid sequence at the phosphorylation site of protein phosphatase inhibitor I. FEBS Lett $76: 182$

Received: August 1, 1979, and in revised form: November 1, 1979

Dr. R. M. Denton

Department of Biochemistry

University of Bristol Medical School

University Walk

Bristol BS8 1TD

England 